\title{
Survival language learning syllabuses revisited: a customized functional-notional approach ${ }^{1}$
}

\author{
Antonio Miranda García \\ Javier Calle Martín \\ Ana Belén SÁez Melendo \\ University of Málaga
}

Received: 15 March 2005 / Accepted: 27 October 2005

ISSN: $1697-7467$

\begin{abstract}
Research on survival English syllabuses has been scarce in the last decades. There is nothing worse than the solitude of a teacher facing a course with such characteristics as continuous hesitations about the materials, activities and the learners' needs arise every now and then. Our contribution stems from Nation and Crabbe's article "A Survival Language Learning Syllabus for Foreign Travel" published in System in 1991, where a topic-based syllabus is proposed. The two-year experimental use of Nation and Crabbe's model, though successful, unveiled some shortcomings having to do with the inventory of situations and the lexical domain included therein. In the light of the limited period of instruction and the short-term benefits that these courses usually hold, a functional/ notional model has been designed for the purpose inasmuch as students seem to gain a wider scope at the end of the learning process.
\end{abstract}

Keywords: Communicative; Functions; Needs analysis; Notions; Planning; Situations; Survival English; Syllabus design; Vocabulary

RESUMEN: La investigación en torno a la programación de un curso de inglés de supervivencia ha sido bastante escasa en las últimas décadas, basada casi exclusivamente en la publicación de libros de texto, la mayoría aplicados a la enseñanza del inglés como segunda lengua. La presente contribución parte del artículo de Nation y Crabbe "A Survival Language Learning Syllabus for Foreign Travel" (1991), donde se propone un enfoque basado en tareas. El empleo del modelo propuesto por Nation y Crabbe, aunque positivo en cuanto a los resultados, revela algunas deficiencias relacionadas fundamentalmente con el inventario de situaciones así como el componente léxico de las mismas. Estos cursos, por lo general, se caracterizan por su escaso número de horas así como por las expectativas en los resultados. Por lo tanto, en el presente artículo se propone un modelo funcional/nocional para los cursos de estas características que permite obtener una mayor competencia comunicativa por parte de los alumnos.

Palabras clave: Análisis de necesidades; Diseño de programación; Enfoque comunicativo; Funciones; Inglés de supervivencia; Nociones; Situaciones; Vocabulario.

${ }^{1}$ We would like to thank Dr. Paul Nation (Victoria University of Wellington) for the painstaking work of reading an earlier draft of this paper and for his useful comments. 


\section{INTRODUCTION}

Survival English syllabuses are the Cinderella of syllabus design in the light of the little attention received in the last decades. As far as we have been able to research, publications on the topic are scarce, being just limited to some handbooks (Johnson, 1980; Mosteller, 1984; Walsh, 1984; Viney and Curtin, 1992; Viney, 1996) and a few websites containing syllabuses for beginners ${ }^{2}$ in an ESL context. Our contribution stems from Nation and Crabbe's article titled "A Survival Language Learning Syllabus for Foreign Travel" (1991: 191-201). Their topic-based syllabus provides a guide for those people in the need of speaking a foreign language for the first time. Given the limited time investment which is generally available to develop this type of course, the syllabus was designed to afford short term benefits, focusing on spoken English and on vocabulary.

Nation and Crabbe's model was adopted in our university to prepare engineering students for a visit to further study or work in an English speaking country. The final assessment showed that the students' communicative competence had been significantly improved and, besides, both lecturers and students got satisfied with the course development and the results obtained. This survival course was repeated with minor modifications during two academic years. However, when we later interviewed the students who had been abroad, it was somewhat disappointing to hear their comments about their communication difficulties, hence constituting a valuable feedback about its shortcomings. On the one hand, they chiefly referred to ordinary situations not included in the syllabus and, on the other, suggested that the lexical inventory should be revised to include new items.

For these reasons, a functional-notional syllabus was implemented so that it could better suit our students' needs by taking into account particular features such as age, mother tongue, language level, background knowledge, etc. This model, with few adaptations, was designed to cope with the linguistic problems that the students usually have in their first visit to an English-speaking country. Our syllabus was developed with the following objectives in mind: 1) to remedy our students' shortcomings by means of a survival model; 2) to check the validity of a functional-notional approach for this type of course; 3) to assess the students' motivation and acceptation of our model by incorporating computer-based sessions in the language lab. All in all, our model of survival English syllabus is featured by its versatility, as it may be adopted in any teaching environment, and its coverage and scope, as it enables the students to cope with most situations in ordinary life.

\section{The Development of a SURVival SYllabus}

This sections deals with the issues that must be considered in the design of a syllabus, namely, a) a needs analysis; b) the criteria for selecting the linguistic material; and c) the sequencing of that material.

\footnotetext{
${ }^{2}$ http://www.hartfordpl.lib.ct.us/tap/se_syllabus_menu.htm; http://www.escort.org/products/ p1718.pdf.
} 


\subsection{Needs analysis}

The needs analysis is generally carried out to obtain, using Hutchinson and Water's terms, reliable data about the learner's lacks and needs (1987: 55-58). Our study, partially based on the model proposed by Dudley-Evans and St. John (1998: 125), covers an analysis of the present and the target situations.

The data for the present situation analysis (Jordan, 1997: 29) were collected from a questionnaire and a series of language tests that were administered to 30 students before the teaching process (see appendix 1). The questionnaire was intended to collect the students' personal details, a self assessment of their level of English and other comments. The tests, on the other hand, prepared to measure their actual level of English, comprised half-dialogues, cloze tests, multiple choice exercises and vocabulary tests. From the questionnaire we concluded that a) the students were mostly in their twenties; b) they claimed to have a non-homogeneous level of English (ranging from beginner to high intermediate); c) they were better skilled for reading and writing than for aural/oral skills, which showed a previous grammar-based learning; and d) they were highly motivated since they acknowledged the need of English for exchanging technical information and considered that English was a valuable asset to find a job. The results of the tests, however, greatly differed from their self-assessment as most of them (19 out of 30) should be considered as false beginners. More accurate was the evaluation of their linguistic skills and vocabulary, as almost all of them admitted their own limitations.

The target situation analysis was accomplished by means of a questionnaire and two interviews (see appendix 2). The questionnaire was administered to the same subjects as above who had to provide information about a) the situations where they were supposed to need English; b) their roles in those situations; c) the level of formality required; and d) the vocabulary needed to interact. For the sake of reliability both English and Spanish were allowed to fill in the questionnaire. With all the information gathered, a first draft was prepared.

Next, this draft syllabus was submitted to a further analysis. For this purpose, eleven students already returned from their Socrates stay abroad revised it so as to add or delete items (functions, notions, situations and vocabulary) in the light of their experience abroad. Later, they were also interviewed so as to justify their modifications, which eventually served to modify this first draft. The feedback provided was helpful inasmuch as the main linguistic difficulties of the students in their first experience in a foreign country could be ascertained, thus helping to update and customize our proposal year after year. For instance, among many others, the following were suggested: how to address a lecturer properly, what to say to open a bank account or apply for a credit card, at the surgery, at a bank, when telephoning or expressing their preferences.

Additionally, to obtain a more reliable analysis, some last-year students of English Philology were also interviewed after their Socrates semester abroad. The interviewees were first given the updated draft for their review so that they could suggest worthwhile modifications during the interview. To warm up the atmosphere and make communication more fluid, some general questions were made about their stay (e.g. the place and time, the university visited, the subjects studied, etc.). Then, in an attempt to make a joint review of the draft and to check their opinions conveniently, three types of questions were made concerning: a) the functions and notions which should be included or excluded; b) the exponents they would use to 
express those functions or notions; c) the situations more difficult to handle, and d) the vocabulary they had learnt because of its usefulness. In a further stage the data recursively elicited were taken into consideration and eventually scheduled in the final draft. As samples of their contribution, suffice it to mention the following: what to say to make a proposal or to refuse an invitation, how to express likes and dislikes, the ways to ask and express one's opinion, etc. Moreover, they also spotted that common difficulties arose when travelling in the underground, trying to make themselves understood in a pub and ordering in fast-food and take-away restaurants. Finally, the vocabulary connected with these situations was also checked. For instance, the terms suggested in relation to the ways of transport were fare, single and return ticket, commuter, delay, platform, carriage, timetable, etc.

\subsection{Selection criteria}

After the needs analysis, all the information gathered so far was examined to select the material which would eventually constitute the survival syllabus since some items had to be discarded due to time restrictions. Different criteria, however, were followed depending on the syllabus constituents (e.g. functions and notions, vocabulary, situations and grammar). First, as for functions and notions, the most important selection factor lay in their potential multi-purpose uses. Therefore, the more likely a given function or notion may occur in different situations, the higher the selection rank will be. Accordingly, the most versatile function is how to ask for and give information that, in turn, leads to notions like how to ask and tell personal details, how to ask and tell about quantity, how to ask for possession, how to ask and express likes, dislikes and preferences, how to ask for permission and grant it, how to ask and give opinion, how to ask for help, how to ask for directions, etc.

It is well-known that specific notions derive from functions when a given situation is involved and, therefore, vocabulary is also selected on the same grounds. As for the situations, the only factor employed comes from the students' feedback as it is futile to include situations that are unlikely to take place (e.g. think of addressing the Commons in Whitehall, betting at Epson Downs, or weather-forecasting on BBC). To complete this picture, the vocabulary gathered was checked against four word-frequency lists ${ }^{3}$ in such a way that a high-frequency word would be preferred to a less frequent one. In this vein, most high-indexical or procedural words should be included at all costs while lexical words would only be selected on the basis of their frequency, but also in terms of their coverage, whenever possible. Finally, for the selection of the grammar items we consulted Biber's frequency list of spontaneous speech (1988: 268) and, especially, those diverging structures if English and Spanish are compared.

\subsection{Material sequencing}

A topic-based syllabus can be easily arranged by picturing the sequence of the students' activities abroad. For instance, they usually travel by plane and, hence, they are bound to change some money at the airport, ask for their luggage, then take the underground/ train/bus/

${ }^{3}$ Brown's 1,000 Most Common Words (http://www.giwersworld.org/computers/linux/common-words.html); Ogden's Basic English Word Listwith 850 words (http://www.langmaker. com/wordlist/basiclex.htm); Nation and Thomas' classification of the thousand word little language (1998, pp. 149-162); and Greenbaum and Svartvik's London-Lund Corpus of Spoken English (http://khnt.hit.uib.no/icame/manuals/LONDLUND/ INDEX.HTM). 
coach/taxi to somewhere else, find accommodation, eat outside and/or cope with social needs until their arrival at the university/firm. In the case of a functional-notional syllabus, the arrangement of functions and notions is carried out in terms of the situations in which they will occur so as to favour their multivalent use after presentation, which means that frequent functions and notions were generally presented before those of lower occurrence. Nonetheless, the arrangement of this bulk of linguistic material, usually intermingled, is often intricate and cannot always be overcome successfully.

The resulting syllabus, modelled according to Nunan's broad view, also includes peripheral elements such as grammar contents and activities (1988: 5; 1988, 87-91). It is divided into nine units which, in turn, comprise five well-defined sections: 1) the functions and notions, along with their exponents; 2) and 3) the situations and the vocabulary; 4) the grammar; and 5) the activities.

\section{Methodological approach}

\subsection{The course}

As the survival syllabus was designed for industrial engineering students (around 30) preparing to continue their studies in an English speaking country, the main objective of the course was to develop their communicative competence in English so that they might cope with frequent situations in ordinary life, without overlooking those university-related. Then it follows that oral/aural skills will receive outstanding attention, their development requiring most of the class time.

\subsection{The development of a unit}

To a certain extent, Nunan's three stages will be used to develop the situations, say, the processing stage by using guided activities, the productive stage with role plays, and the interactive stage by means of rehearsals, discussions and debates (Nunan, 1988: 54). Accordingly, a sample unit consisting of five sections is explained below. A 60-minute session corresponds to each of them.

In the first, the teacher presents the selected functions and notions emphasising their importance and possible uses, generally by means of videos or specific software. Then, with a warming-up activity he tries to activate the students' potential knowledge and, thus, obtain valid exponents for each notion. The blackboard may be used to collect the information provided by the students; this information is later completed by the teacher who can also use handouts, or slides for the overhead projector. This technique has proved to be effective because it allows to: 1) activate the students' previous knowledge; and 2) favour oral communication.

Next, in the second and third sessions, new situations are introduced to practice the exponents of the functions and notions concerned. However, more often than not the lack of vocabulary hinders the successful completion of the activity, that is why the situations and the vocabulary are held together. As for vocabulary, on the other hand, the following remarks should be made: 1) both procedural and lexical vocabulary need to be practiced so as to 
improve the students' word stock; 2) only the vocabulary included in the syllabus is presented, though it may be augmented at the students' request; and 3) the vocabulary is always practiced within a context. Methodologically, the teacher may use all kinds of realia as well as other auxiliary means to achieve the target. In this fashion, the full knowledge of words is reinforced (e.g. synonyms, antonyms, lexical families, etc), especially the syntagmatic links between them just by connecting nouns, verbs and adjectives (Carter, 1987: 33-41). For instance, as suggested by Higa (1983: 170-175), when dealing with the function to express one's likes and dislikes, we resort to the food-related vocabulary (e.g. egg, bread, fruit, meat, rice, chips, salad, hamburger, fish, custard, etc.), along with those terms used to name their colour, taste, size, shape, weight, price, etc. Thus, if bread were the hiperonym selected for coverage reasons, then nouns such as loaf, roll, bun, toast, slice, etc. might be prompted as well as related adjectives like fresh, stale, white, brown, whole, etc. and those verbs like cut, toast, slice, bake, etc. so that meaningful utterances may be produced and, at the same time, the links between closely-related words may be strengthened.

In the fourth session, some brief chalk talks are imparted to explain the structures that diverge from those in their mother tongue. Their inclusion in a given unit is determined by their occurrence in the exponents of the functions and notions studied. For example, that is the case of those structures used for making questions, practically needed elsewhere throughout the syllabus. Specific software is also used in a computer-equipped room, as individual work is allowed without any time restriction.

Finally, there is a session devoted to perform the activities where pair work is preferred as a preparation for the eventual communicative exchanges.

\subsection{The assessment}

The students' assessment is carried out by means of an oral exam at the end of the term using the same techniques as in the course to make them interact with the teacher or with another student. All kinds of materials are employed so as to simulate real communication, which is tape-recorded for analysis, self-correction and final evaluation. Their vocabulary, however, is checked by using similar tests to the ones used in the course.

\section{The SURVival SYllabus}

Below we include the nine units into which our syllabus has been divided. In each of them five different parts are distinguished, namely, a) functions and notions and their exponents; b) situations; c) grammar; d) lexis and e) activities. Although omitted for the sake of brevity, most of these activities have been taken from Littlewood (1981), Nation and Thomas (1988), Nunan (1989) and Rinvolucri (1990).

\section{UNIT 1}

\subsection{Functions, notions and exponents}

How to say hello:

Hello / hi, how are you? Fine, thank you, and you? / Not so bad / Not so good 
Hello, how are things? / how's it going? OK, thanks and you? Up and down / we mustn't grumble

It is nice / good to see you again

It has been a long time! / It is ages since I saw you!

Long time no see!

\section{How to introduce yourself and others:}

Hello, my name is / I am ...

How do you do?

Do you know each other? / Have you met before?

Let me / may I introduce you to ...

Mary, this is Tom, Tom, this is Mary

Nice / pleased to meet you

\section{How to ask and tell your personal details:}

What is your name / telephone number / e-mail / address, etc?

Can you spell that?

Where are you from? / where do you live? / where were you born?

Where did you study?

Do you have any job experience?, how long have you been working as a ...?

\section{How to interrupt:}

Excuse me / sorry

May I interrupt for a moment?

Sorry to disturb / interrupt you

Could I have a word with you?

Can I speak to you for a moment?

Do you have a minute?

\section{How to greet and take leave:}

Good morning / afternoon / evening / night

It has been nice / a pleasure talking to you

Goodbye / Bye

So long! / be seeing you! / Cheerio!

(I'll) see you soon / tomorrow / next week / later

\section{How to express gratitude:}

Thank you / thanks a lot / thanks ever so much! / Ta!

I'd like to thank you for ...

I am extremely grateful to you for ...

\subsection{Situations}

- Socialising in the plane

- At the airport 
- picking up your luggage

- changing money

- asking for information

- Looking for a job

- at a job interview

- exposing your résumé

- At a friends' party

\subsection{Grammar}

- Verb tenses: review

- Subject / object pronouns

- Subject / verb agreement

- Yes / no and wh- questions

\subsection{Lexis}

- Forms of address

- Place names

- Week days and months

- The alphabet

- Education

- School subjects

- Professions

\subsection{Activities}

\section{UNIT 2}

\subsection{Functions, notions and exponents}

How to describe people (physically, emotional states and characters):

How is he / she like?

How do you feel?

How to describe people's appearances:

What is he / she wearing?

What kind / sort / type of clothes is he wearing?

How to describe houses and objects:

How big / large / heavy / high / long / deep / wide is it?

What is the height / width / length of ...?

What colour / shape is it?

What material is it made of? 
How to ask and tell about quantity / units of measure:

How much / many?

There is / are some (uncountable / countable nouns)

How to express family relationships:

Who is he? He is ...

How to ask for possessions:

This is mine / yours / his / hers ...

Whose car is this?

Tony's car

\subsection{Situations}

- Looking for accommodation

- types

- matching people to live with

- sharing a flat

- describing your house

- road and city terms

- using a map

- reading public notices

- Going shopping / at the department store / bookshop

- A family tree

\subsection{Grammar}

- Noun and verb phrase structure

- There is / there are

- Demonstratives and possessives

- Adverbs of frequency

- Much / many / some / any / a few / little / a lot of / lots of

- To have

\subsection{Lexis}

- Emotional states and characters

- People's appearances

- Family terms

- Clothes

- Materials (including properties, shapes, external surface, aspect)

- Adjectives to describe clothes (fit, style, appearance, pattern)

- Public notices

- Houses

- Indoor terms

\subsection{Activities}




\section{UNIT 3}

\subsection{Functions, notions and exponents}

\section{How to express likes and dislikes:}

Would you like to ...? Yes, I'd like to / I'd love to ...

Do you like / dislike / loath / detest / hate ...?

Do you feel like / fancy ...?

I am fond of / keen on; I look forward to ...

I can't stand / bear / put up with ...

\section{How to express preferences:}

Which one would you prefer / rather have?

Do you have any preference?

I think I'd rather / I'd prefer ...

\section{How to seek for permission:}

Can / could / may / might I (possibly, perhaps) ...?

Will you let me use your ...?

Am I allowed to ...?

Would / do you mind if I use ...?

Will / would you permit me to use your ...?

I wonder if I could / might use ...?

Would it be possible for me to use ...?

Is it possible to use the ...?

\subsection{Situations}

- At the café / take-away

- Talking about hobbies

- Buying food and drinks

- at the grocer's

- at the baker's

- at the stationary

- At the bank

- hours of bank operation

- opening an account

- asking for a credit card

- cashing a traveller check

- making money orders

- making deposits and withdrawals

- Understanding traffic signs

\subsection{Grammar}

- Modal verbs

- Causal clauses 
- Like + noun / verb (-ing)

- Word order

\subsection{Lexis}

- Methods of payment

- Bank and money terms

- Words and expressions relating to liking and disliking

- Food and drink terms

- Methods of cooking

- Units of measure

- Do and make

\subsection{Activities}

\section{UNIT 4}

\subsection{Functions, notions and exponents}

\section{How to express certainty:}

1. Certainty

I am sure / certain that ...

He is definitely / undoubtedly ...

There is no doubt that ...

2. Probability / improbability / impossibility

He is likely / probable to ...

It is possible that ...

Is there any chance / possibility that ...?

It may / might

It is unlikely / impossible / improbable (that) ...

3. Uncertainty

I am not sure / doubt that / am a bit uncertain that ...

It is doubtful / doubtless (that / whether) ...

4. Guesses

I would say / reckon / speculate that ...

How to talk about frequency; how to tell the time:

How often ...? Once a day, twice a week, etc.

From one to three

What time is it? / What's the time?

\subsection{Situations}

- Talking about the weather

- Socialising / going out

- practising sports 
- going to the cinema

- watching television

- renting a DVD / video tape

\subsection{Grammar}

- Conditional clauses

- If only / I wish

- Negative phrases and clauses

\subsection{Lexis}

- Verbs of certainty

- Seasonal / weather terms

\subsection{Activities}

\section{UNIT 5}

\subsection{Functions, notions and exponents}

How to ask and give information / opinion:

What do you think of ...?

What is your view of / your opinion of ...?

Do you reckon that ...?

I think / believe / am convinced / have always held that ...

My view is that / in my view / in my opinion / to my mind ...

How to agree and disagree:

I agree / am in agreement with / am for ...

You can say that again!

It goes without saying ...

I do not agree / disagree / am against ...

\subsection{Situations}

- At the doctor's / chemist's

- Expressing points of view

- At the post office

- posting letters / parcels

\subsection{Grammar}

- Wh- questions

- Question tags 
- Reported speech

- Clauses of reason

\subsection{Lexis}

- Parts of the body

- Phrases to express opinion

- Conversation-building expressions

\subsection{Activities}

\section{UNIT 6}

\subsection{Functions, notions and exponents}

\section{How to ask for help:}

I wonder if you could help me / I am looking for some help

Can you help me? yes, of course / no, I'm afraid I can't

May I help you?

How to ask for directions indoor and outdoor:

Can you tell / show me the way to ...?

How do I get to ... from here?

Could you direct me to ...?

I am looking for ...

Turn left / right; branch off; take the first left

Go straight on / ahead

How to ask and say where places are:

Where is it?

How far is it? $300 m$ far from here

How are you going? By car / by bus / by underground / on foot

\subsection{Situations}

- Phoning a friend

- Finding places indoor and outdoor

- At the underground

- following a tube map

- In the street (sightseeing)

\subsection{Grammar}

- Will / shall

- The present continuous to express future events 
- Going to

- Infinitives to express purpose

\subsection{Lexis}

- Adverbs and prepositions to indicate location

- Ways of travelling

- City terms

- Reading road signs

- Sightseeing terms

\subsection{Activities}

\section{UNIT 7}

\subsection{Functions, notions and exponents}

How to make and answer telephone calls:

I would like to make a phone call

Can I speak to ...? Speaking

Who's calling?

Can you put me through to ...?

Hold the line / hang on a minute

Can you speak up ...?

We have a crossed line / been cut off

The line is engaged / busy

Could you reconnect me, please?

I will ring you back

Can I leave a message?

You are wanted on the telephone!

How to talk about the time (opening and closing times):

What time does the ... open / close / begin?

When does it leave / arrive?

How long does it take?

\section{How to remind and complain:}

Don't forget to / remember to / may I remind you that ...?

Can I see the the person in charge?

I'd like to make a complaint / wish to complain about ...

I'll see what I can do

I'll pass your complaint on to the manager

\subsection{Situations}

- At the hotel / B\&B

- asking for someone at a hotel

- making hotel / restaurant reservations 
- At the train / coach station / bus station

- asking for timetables

- buying a ticket

- payment methods

- Renting a car

\subsection{Grammar}

- How to express time relationship

- Modal verbs

\subsection{Lexis}

- Linkers (previous, simultaneous and subsequent actions / time when)

- Time-related phrases

- Remind vs. remember

- Public transport

\subsection{Activities}

\section{UNIT 8}

\subsection{Functions, notions and exponents}

How to make, accept and decline offers, invitations and suggestions:

May I

...

Let / allow me to ...

Would you like to come to ...

We would like to invite you ...

Why don't you come?

Do you feel like ...?

I'd like to make a suggestion ...

What about ...

Thanks, I'd love to / I'd be delighted to / that sounds nice

\section{How to apologise:}

I am sorry, I am afraid that

...

I'd love to, but I am busy / booked up, some other time

Thank you for the invitation but I am afraid I have to say no

Excuse me, I apologise for not ...

\section{Persuading:}

Why don't you? / Why not come with us?

Do come and-... 
I think you ought to ...

Can I persuade you to? I insist ...

\subsection{Situations}

- Invitations for going out

- Eating out

- Declining a party proposal

\subsection{Grammar}

- ing forms

- Contrast clauses

- Let's ...

\subsection{Lexis}

- Amusement terms

\subsection{Activities}

\section{UNIT 9}

\subsection{Functions, notions and exponents}

How to give instructions, advice and warnings:

Don't do it!

Are there any instructions? / How does it work / function?

All you have to do is ...

You must always remember to ...

I need some advice about ...

Can you advise me as to what I should do?

Can you give me any advice?

My advice would be to ... / If I were you, I would / You'd better not

I should warn you that ...

Take care (of) ....

Mind your ... ! / Be careful! / Watch out! / Look out!

\section{How to express obligation:}

I must / have (got) to-...

I am obliged to / liable to / forced to ...

He had no choice / alternative ...

This is compulsory / obligatory

\subsection{Situations}

- At the college / university

- asking about subjects and class timetables

- choosing between subjects 
- talking to lecturers

- e-mailing tutors

- working in the library

- requesting books

- Defining or asking for a definition

- Paraphrasing and summaring

- Explaining

- Comparing or contrasting

- Evaluating the results of an action

\subsection{Grammar}

- Imperatives

- Like + noun / verb (-ing)

- Word order

\subsection{Lexis}

- University terms

\subsection{Activities}

\section{Conclusions}

The syllabus presented here was put into practice during two successive academic years and the results showed that the students have improved their communicative competence as well as their command of vocabulary. The assessment after the teaching process together with the students' own feedback after their stay abroad led us to conclude that the they gain a wider communicative competence with a functional syllabus rather than with a topic-based syllabus, the latter being more restrictive in the selection of structures and vocabulary. Therefore, we have grounds to state that the initial objectives of this paper have been positively accomplished inasmuch as our students' communicative weaknesses when interacting in English are greatly solved, especially when ordinary situations are involved. Moreover, the level of acceptance of the methodology and the auxiliary means used must also be considered as satisfactory.

However, as the teaching of a foreign language must always be considered as a dynamic process, we are constantly receiving the feedback from our students to obtain both the strong and the weak points of our proposal. This continuous process of revision and implementation of the syllabus will allow us to develop an ever-enriching model which, without any doubt, will lend itself to be used in any teaching context.

\section{REFERENCES}

Biber, D. (1988). Variation across Speech and Writing. Cambridge: Cambridge University Press. Carter, R. (1987). Vocabulary. London: Allen \& Unwin.

Dudley-Evans, T. and St. John, M.J. (1998). Developments in English for Specific Purposes. Cambridge: Cambridge University Press. 
Finocchiaro, M. and Brumfit, C. (1983). The Functional-Notional Approach. New York: Oxford University Press.

Higa, M. (1983). "Interference Effects of Intralist Word Relationships in Verbal Learning", in Journal of Verbal Learning and Verbal Behaviour, 2: 170-175.

Hutchinson, T. and Waters, A. (1987). English for Specific Purposes. A Learning-centred Approach. Cambridge: Cambridge University Press.

Johnson, M. (1980). Survival English from Newcomers: The Tutor's Handbook. Vinnipeg: Clarity Books.

Jordan, R.R. (1997). English for Academic Purposes. A Guide and Resource Book for Teachers. Cambridge: Cambridge University Press.

Littlewood, W. (1981). Communicative Language Teaching. An Introduction. Cambridge: Cambridge University Press.

Mosteller, L. (1984). Survival English: English through Conversations. New Jersey: Prentice Hall.

Munby, J. (1978). Communicative Syllabus Design. Cambridge: Cambridge University Press.

Nation, P. and Thomas, G.I. (1988). Communication Activities. Wellington: Victoria University of Wellington.

Nation, P. and Crabbe, D. (1991). "A Survival Language Learning Syllabus for Foreign Travel”, in System, 19 (3): 191-201.

Nation, P. (2003). "Learning Vocabulary in Lexical Sets: Dangers and Guidelines". Unpublished paper.

Nunan, D. (1988). Syllabus Design. Oxford: Oxford University Press.

Nunan, D. (1989). Designing Tasks for the Communicative Classroom. Cambridge: Cambridge University Press.

Rinvolucri, M. (1990). Grammar Games. Cognitive, Affective and Drama Activities for EFL Students. Cambridge: Cambridge University Press.

Rivers, W. (1981). Teaching Foreign Language Skills. Chicago: University of Chicago Press.

Van Eek, J. and Alexander, L.G.. (1975). Threshold Level English. Oxford: Pergamon Press.

Viberg, A. (1989). "A Semantic Field Approach to Vocabulary Acquisition". Unpublished paper.

Viney, P. and Curtin, J. (1992). Survival English. International Communication for Professional People. Oxford: Macmillan Heinemann.

Viney, P. (1996). Basic Survival. Oxford: Macmillan Heinemann.

Walsh, R.E. (1984). Basic Adult Survival English with Orientation to American Life. Parts I and II. New Jersey, Prentice Hall.

Wilkins, D.A. (1976). Notional Syllabuses. A Taxonomy and Its Relevance to Foreign Language Curriculum Development. Oxford: Oxford University Press. 


\section{Appendix 1. Present situation analysis}

1. Personal details

- Name:

- Date of birth:

- Birthplace:

- Sex:

- Foreign language studied (whether compulsory or optional):

- Previous instruction of English (in years):

- Evaluate your level of English as (tick the appropriate box):

Beginner

Pre-intermediate

Intermediate

Post-intermediate

Advanced

- Rate your skills in English (from 0 to 5).

Reading

Writing

Listening

Speaking

- Have you ever been to an English speaking country?

- How long did you stay there? Specify the object of your visit.

- Other comments.

2. Language test

2.1. Half-dialogues

2.2. Assisted clozes

2.3. Multiple choice tests

2.4. Vocabulary tests

2.4.1. Single the odd one out

2.4.2. Match (term and its definition, viceversa, synonyms, antonyms)

2.4.3. Supply the missing word 


\section{Appendix 2. Target situation analysis}

\subsection{Questionnaire}

a) Underline the most likely situations where you can be involved (e.g. at the airport, station, take-away, restaurant, B\&B, hotels, etc.). Suggest some others that you consider of importance.

b) For each of the above situations,

- specify your role (e.g. as a client, student, mate, traveller, etc.).

- specify the level of formality required (whether formal, informal, slang, etc.).

- supply the vocabulary needed. Include, if possible, nouns, adjectives, verbs and adverbs (e.g. at the airport, exit, baggage claim, luggage, flight ticket, gate, check-in desk, delay, early, late, take off, land, check in, check out, in time, etc. were provided).

\subsection{Interview}

To check the data collected in 2.1, students are allowed to suggest new items or delete some others in the light of their experience abroad.

\subsection{Interview}

To check the results obtained so far (from 2.2.). 